\title{
CLP1 wt Allele
}

National Cancer Institute

\section{Source}

National Cancer Institute. CLP1 wt Allele. NCI Thesaurus. Code C97529.

Human CLP1 wild-type allele is located in the vicinity of $11 \mathrm{q} 12$ and is approximately $13 \mathrm{~kb}$ in length. This allele, which encodes polyribonucleotide 5'-hydroxyl-kinase Clp1 protein, is involved in the mediation of RNA maturation. 